\title{
OCCURRENCE OF ALLOCHTHONOUS FRESHWATER CRAYFISHES IN LATIUM (CENTRAL ITALY)
}

\author{
S. CHIESA (1)*, M. SCALICI (2) AND G. GIBERTINI (3)
}

Università degli Studi "Roma Tre", Dipartimento di Biologia, viale G. Marconi 446, 00146 Roma, Italy.

(1) * Corresponding author: ztef@inwind.it

(2) scalici@uniroma3.it

(3) gibertin@uniroma3.it

Reçu le 23 mai 2005

Accepté le 23 décembre 2005

Received May 23, 2005

Accepted December 23, 2005

\begin{abstract}
The introduction of animal species, transfaunation and habitat destruction are among the greatest threats for biodiversity. In fact, in the water systems of Latium the occurrence of allochthonous crayfishes Procambarus clarkii, Orconectes limosus and Astacus leptodactylus has been observed. The distribution of these species in Latium highlighted some differences between them: Orconectes limosus and Astacus leptodactylus are present in restricted areas, while Procambarus clarkii has a wide distribution throughout the region. The present study confirmed their ecological plasticity, strong capability of invasion and adaptation to new environments of all three species, due to their rapid growth, utilisation of different trophic resources and the frequency and length of their reproduction periods. These aspects can cause irreversible ecologic and economic damage. The eradication of Procambarus clarkii would be a difficult task, because of its wide distribution and the many records of the species, especially in the Province of Latina, where complex field irrigation systems are found. All the agencies for environmental protection should increase control activities, with a serious field effort. As regards the other two species, eradication would be easier due to their limited distribution. It is important to avoid the spreading of these species; this can be done through public opinion awareness-raising campaigns and a continuous control on the region, increasing research and supporting it with new laws concerning the introduction and treatment of alien species.
\end{abstract}

Key-words: allochthonous freshwater crayfishes, Procambarus clarkii, Orconectes limosus, Astacus leptodactylus, central Italy.

\section{PRÉSENCE D'ÉCREVISSES ALLOCHTONES DANS LE LATIUM (ITALIE CENTRALE)}

\section{RÉSUMÉ}

L'introduction d'espèces animales, la transfaunation et la destruction de l'habitat font partie des menaces les plus graves sur la biodiversité. La présence des écrevisses allochtones Procambarus clarkii, Orconectes limosus et Astacus leptodactylus a été observée dans les eaux douces du Latium. L'étude de la distribution de ces espèces dans le Latium fait ressortir quelques différences: Orconectes limosus et Astacus 
leptodactylus sont limitées à des zones restreintes, tandis que Procambarus clarkii a une large distribution sur tout le territoire. Le présent travail confirme la plasticité écologique et la forte capacité d'invasion et d'adaptation à de nouveaux environnements de ces trois espèces, dues à leur croissance rapide, à l'utilisation de différentes ressources trophiques ainsi qu'à la fréquence et à la durée de leurs périodes de reproduction. Ces aspects peuvent engendrer des dommages écologiques et économiques irréversibles. L'éradication de Procambarus clarkii serait une tâche difficile, à cause de sa large distribution et des nombreux signalements de cette espèce, surtout dans la province de Latina, où des systèmes complexes d'irrigation sont présents. Toutes les agences de protection de l'environnement devraient augmenter leurs activités de contrôle, avec un effort particulier sur le terrain. Concernant les deux autres espèces, l'éradication serait plus facile du fait de leur distribution restreinte. II est important de limiter la diffusion de ces espèces; ceci peut être réalisé grâce à des campagnes de sensibilisation du public et à un contrôle permanent et efficace en favorisant la recherche et par de nouvelles réglementations sur l'introduction et le traitement des espèces allochtones.

Mots-clés: écrevisses allochtones, Procambarus clarkii, Orconectes limosus, Astacus leptodactylus, Italie centrale.

\section{INTRODUCTION}

The term "allochthonous" refers to an alien species, which occurs in a given area or ecosystem and that can be found outside its historical distributional area as a result of dispersion caused by man (transfaunation) and not by the intrinsic potential of the species (SCALERA, 2001).

The introduction of animal species (together with habitat destruction) is one of the greatest threats for biodiversity (GENOVESI, 2002). Biological invasions give raise to numerous severe consequences not only at an ecological level, with predation and competition, but also at a genetic, economic (i.e. damages to agriculture, fishing and aquaculture) and sanitary (spreading of pathologies and parasites) level. These problems affect numerous plant and animal species, including freshwater decapods, which have been imported from various countries and are now widespread in Europe (HOLDICH, 2003).

In Italy there are numerous species: Procambarus clarkii (Girard, 1852), Orconectes limosus (Rafinesque, 1817), Astacus leptodactylus (Eschscholtz, 1823), Pacifastacus leniusculus (Dana, 1852), Cherax destructor (Clark, 1936) and C. quadricarinatus (von Martens, 1868). Among these, the last two have never been observed in nature, but are reared in specific aquaculture farms (GHERARDI et al., 1999a).

In the water systems of Latium the occurrence of allochthonous freshwater crayfishes Procambarus clarkii and Orconectes limosus, Cambaridae coming from North America, and Astacus leptodactylus, Astacidae coming from Eastern Europe, has been observed (QUATTROCCHI et al., 1996; SCALICI and GIBERTINI, 2002).

In Italy, Procambarus clarkii has been observed for the first time in 1989 in Piedmont (DELMASTRO, 1992a), and later in numerous northern and central provinces (GHERARDI et al., 1999a). In Piedmont and Emilia Romagna this species is already naturalized in many areas of the river Po basin, and one of the major threats concerns its spreading in irrigation canals near Vercelli and Pavia, since the construction of burrows along their banks may damage, causing a collapse, the water system in rice fields, these being the favourite habitat of this species (CORREIA and FERREIRA, 1995; SALVI, 1999; GHERARDI and BARBARESI 2000). In central Italy Procambarus clarkii is widespread in Tuscany, especially near the lake Massaciuccoli, in Versilia (province of Lucca, Massa, Carrara), up to the river Magra in the nearby region of Liguria (province of Genoa), near Pisa, in the province 
of Florence (Osmannoro and Sesto Fiorentino), and those of Prato and Pistoia. Their occurrence in Umbria, Abruzzo, Marche and Latium has also been ascertained, especially in the province of Rome and Rieti (GIBERTINI et al., 1998; BARBARESI and GHERARDI, 2000). These last records have been subsequently confirmed by SCALICI and GIBERTINI (2002), who have observed their occurrence in the province of Latina and Viterbo as well. Nonetheless, its occurrence has broadened to many other Italian provinces. New records have been reported even in Sicily (LO VALVO, personal communication). P. clarkii is a species with high dispersion and movement power even outside the water. It is able to move periodically covering up to $17 \mathrm{~km}$ in 4 days (GHERARDI and BARBARESI, 2000). Moreover, it is a very aggressive species, it can indeed, damage the freshwater community, disturbing it especially on heat. Due to its excavating ability, which implies the construction of tunnels used as burrows or shelters during the dry season and the reproductive period, it can set off even severe landslides and landslips in the banks. The tunnels have a regular form. They are surmounted by a bank of land, similar to a chimney, which could play an important role during the oxygenation (HUNER and BARR, 1991).

Until recently, Orconectes limosus was almost unkown in Italy. In fact, its first record in our freshwater courses dates back to 1992 in the Iseo lake (DELMASTRO, 1992b). Subsequently, its occurrence has been signalled in 1993 by GROPPALI in the province of Pavia and later by CONFORTINI and NATALI (1994) in the plains near Verona. In Emilia Romagna its spreading has been highlighted in 1997 (MAZZONI et al.). The first record in Latium dates back to 1996 (QUATTROCCHI et al.) and its occurrence is limited at the moment to the lake of Piediluco (DÖRR et al., 2001) and to the Salto lake. This last record has been confirmed in 2002 (SCALICI and GIBERTINI, 2002).

In Italy, the occurrence of naturalized populations of Astacus leptodactylus has been observed only in the province of Milan, in that of Bologna, in the region of Liguria (river Vara basin, province of La Spezia) and in Latium (GHERARDI et al., 1999a). Its limited expansion in Italian freshwater courses may be due to its high sensibility to the crayfish plague Aphanomyces astaci (Shikora, 1902) (GALLUPPI et al., 1996), of which cambarids are healthy vectors for translocation of the pathogen (ALDERMAN and POLGLASE, 1988), and even to other fungal and parasitic infections, like Thelohania contejeani Henneguy, 1892, which damages the abdominal muscular fibres (MANCINI, 1986). In particular, aphanomycosis is one of the major causes of rarefactions and disappearance of European crayfish populations, which are extremely sensitive to the disease; meanwhile North-American crayfish shows a strong tolerance (MANCINI, 1986). The transport and trade of exotic species has contributed to its spreading over the entire European territory, endangering the survival of indigenous species. Even though the disease is well known over more than a century and its pathogen has long been identified, there is no efficient method that can fight it and successfully defeat it (MANCINI, 1986). However, a special treatment, using precise $\mathrm{MgCl}_{2}$ concentrations, seems to prevent the development of sporanges and, therefore, the transmission of the pathology through sporulation (RANTAMÄKI et al., 1992).

The main purpose of the present work was to increase the information about these species in order to improve management activities and solve or control the problems involved with their occurrence. This situation requires the knowledge of data, which could allow the institutional authorities to take on accurate managerial decisions. This phase can be achieved through the application of predictive patterns that, nonetheless, require a basic knowledge of the species taken into consideration. More in detail, the need to geographically characterize the species resulted from the awareness that obtaining systematically informational data on the distribution of allochthonous crayfish populations is a prerequisite condition to effectively participate to the management of the allochthonous community and the conservation of the autochthonous one. This type of information enables the intervention on two main factors: the dispersion of allochthonous crayfish and the spreading of pathogen agents. Indeed, the knowledge of the populations'distribution 


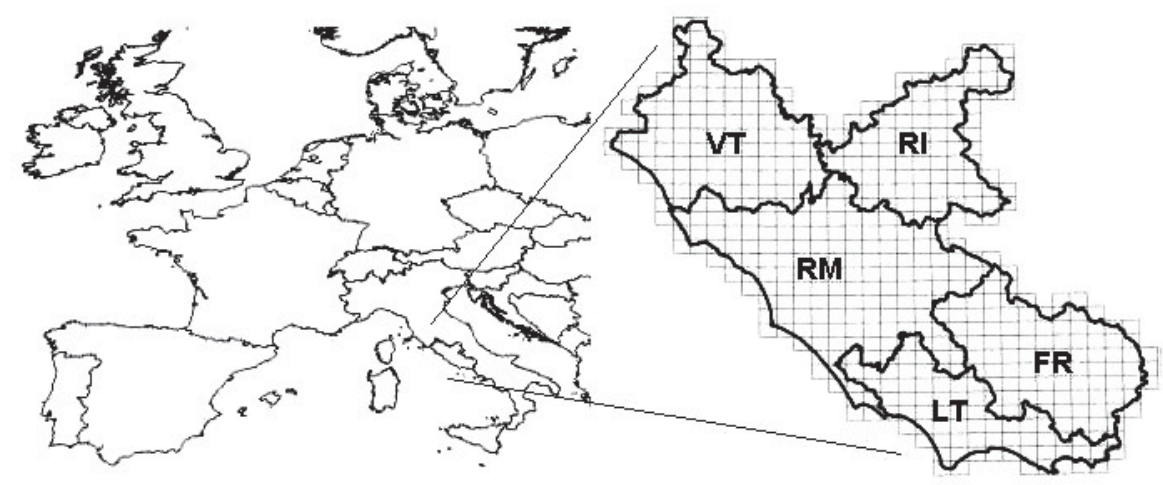

Figure 1

Study area: VT = Viterbo; RI = Rieti; RM = Rome; FR = Frosinone; LT = Latina.

\section{Figure 1}

Région d'étude : VT = Viterbo ; RI = Rieti ; RM = Roma ; $F R=$ Frosinone ; LT = Latina.

in a precise area is the first and most important element that helps evaluate the risk of diffusion and plan a logic prevention programme against transmission.

The aim of the present research is to contribute to the increasing knowledge of the distribution and ecology of freshwater allochthonous decapods in water systems of Latium, especially by providing information on the growth, the diet and the reproductive biology (these last aspects are exclusively referred to P. clarkii and O. limosus).

\section{MATERIAL AND METHODS}

\section{Study area}

Latium is a region in central Italy, covering an area of $17,203 \mathrm{~km}^{2}$ from $41^{\circ} 19^{\prime}$ to $42^{\circ} 80^{\prime} \mathrm{N}$ and from $11^{\circ} 47^{\prime}$ to $14^{\circ} 08^{\prime} \mathrm{E}$, divided in 5 provinces: Viterbo, Rieti, Rome, Frosinone, Latina (Figure 1). All the investigated environments present anthropic disturbances: lakes are characterized by a moderate eutrophism, while field irrigation canals or pounds show bad levels of water quality.

\section{Sampling procedure}

The geographic distribution analysis of allochthonous freshwater crayfishes in Latium was carried out through a bibliographic research, personal communications and field work, the latter conducted during March, May, June, July, August, October, November 2003 and June, July, August 2004. Freshwater crayfishes have been caught making a linear transect along the banks, using hand-nets with different mesh.

The specimens have been measured on the back (along the dorsal mid-line), taking CTL (cephalothorax length, from the tip of the rostrum to the posterior part of the thorax) and TL (total length, from the tip of the rostrum to the end of the telson) using an eyepiece micrometer, then placed in absorbant paper and weighted (W).

The CTL measurements have generated polymodal frequency distribution histograms that have been analysed with the FAO-ICLARM Stock Assessment Tools (FiSAT) computer programme (GAYANILO et al., 1996). This programme enables the decomposition of mixed length-frequency distributions into their Gaussian components by means of BHATTACHARYA's (1967) method. The last one is used to estimate the growth rate of fishes, 
but it has been also successfully used with many other taxa. For example, reptile (SALVIDIO and DELAGUERRE, 2003), mussels (ARDIZZONE et al., 1996), marine crustaceans (LEONARDI and ARDIZZONE, 1994; MERELLA et al., 1998) and freshwater crayfishes (HOGGER, 1984; ZEKHNINI and CHAISEMARTIN, 1991). With this process, each identified component is subtracted from the remainder of the sample using a Gaussian function. A linear regression analysis for each separate component and a $\chi^{2}$ goodness-of-fit statistic for the entire samples were then calculated. In addition, a separation index (S.I.) for each pair of adjacent groups was estimated; when S.I. $\leq 2$, separation between components is unreliable (SPARRE and VENEMA, 1996). Moreover, FiSAT provides the mean, the standard deviation, and the theoretical number of individuals in each group. The results obtained with the Bhattacharya method have been subsequently used to evaluate the growth. The growth has been calculated with the Von Bertalanffy equation, described as follows:

$$
L(t)=L_{\text {inf }}\left[1-\exp \left(-k_{.}\left(t-t_{0}\right)\right)\right]
$$

The mathematical model expresses different growth parameters: $L$ represents the length as a function of the age $t, L_{\text {inf }}$ is interpreted as the mean length of old specimens, $k$ is a curvature parameter which determines how fast the crayfish approaches its $L_{\text {inf }}, t_{0}$ is the initial conditions parameter that determines the point in time when the crayfish have zero length. The latter has no biological significance because on hatching crayfish have well defined dimensions. However, it represents an important parameter to determine the growth curve (SPARRE and VENEMA, 1996). All of the Von Bertalanffy parameters have been calculated by the software STATISTICA Statsoft. In the present research $\mathrm{L}_{\text {inf }}$ has been calculated by applying the following formula routine (included in FiSAT):

$$
\mathrm{L}_{\text {inf }}=\mathrm{L}_{\text {max }} / 0.95
$$

where $L_{\max }$ is the maximum size according to SPEDICATO and CANNAS (2000).

Although the physiology of crustaceans is very different from that of fishes, their average body growth appears also to conform to the von Bertalanffy growth model (GARCIA and LE RESTE, 1981). An individual crustacean does not conform to the Von Bertalanffy model, but to some "stepwise curve", with each step accounting for a moult. However, members of a cohort moult at different times, and therefore the average growth curve of a cohort of crustaceans becomes a smooth curve. For further discussion on the modelling of population dynamics of crustaceans see, for example, JAMIESON and BOURNE (1986) and CADDY (1987). This method has been used with marine crustaceans (ORSI RELINI and RELINI, 1985) and also with freshwater crayfishes (FIDALGO et al., 2001).

Moreover, regression analysis between CTL and other two parameters TL and W (total body weight) have been carried out. The latter was used to obtain the values of the coefficient of condition $\mathrm{K}_{\mathrm{c}}$, calculated according to the following formula;

$$
\mathrm{K}_{\mathrm{c}}=\left(\mathrm{W} / \mathrm{CTL}^{\mathrm{b}}\right) \cdot 100
$$

where $b$ is a species-specific constant and it represents the angular coefficient of the relationship length-weight, which is expressed in terms of natural logarithm:

$$
\ln W=b \cdot \operatorname{lnCTL}+\ln K_{c}
$$

From the specimens caught, the stomach has been drawn out as well, dividing contents in order to study the diet. Also the reproductive cycle has been investigated: from the same animals, gonads have been taken away (including vas deferens and androgenic glands for males), first weighted to obtain the gonadic index (G.I.) calculated by applying the following formula:

$$
\text { G.I. }=W_{g} /\left(W-W_{g}\right)
$$

where $\mathrm{W}_{\mathrm{g}}$ is the gonadal weight. 
Then, the gonads have been used to prepare histological sections, by fixing them with Bouin, dehydration, inclusion with paraffin, and colouring with Carazzi Hematoxylin and Eosin.

\section{RESULTS}

\section{Geographic distribution}

The occurrence of freshwater allochthonous crayfish species has been observed in four of the five provinces of Latium, in 21 sites altogether. Procambarus clarkii is present in the provinces of Viterbo, Rieti, Rome and Latina (17 sites); Orconectes limosus only in the province of Rieti (2 sites), meanwhile Astacus leptodactylus in the provinces of Rome and Rieti ( 3 sites). Table I and Figure 2 show the crayfish's distribution.

Table I

Distribution of allochthonous freshwater crayfishes in Latium. $\mathrm{PC}=$ Procambarus clarkii, $\mathrm{OL}=$ Orconectes limosus, $\mathrm{AL}=$ Astacus leptodactylus . 1,2 Dr P.T. COLOMBARI, pers. com.; ${ }^{3}$ SCALICI \& GIBERTINI, 2002; 4 DÖRR et al., 2001; ${ }^{10} \mathrm{Dr}$ M. IACONELLI, pers. com.; ${ }^{11}$ GIUCCA, 1997; ${ }^{13}$ Park guard, pers. com.; ${ }^{15}$ Prof. P. MARIOTTINI, pers. com.; ${ }^{16}$ Park guard, pers. com.; ${ }^{17} \mathrm{Dr}$ M. LORENZETTI, pers. com.; ${ }^{18} \mathrm{Dr}$ G. MOTISI, pers. com.; ${ }^{19} \mathrm{Dr}$ D. CELAURO, pers. com.; ${ }^{20}$ Dr G. LARICCIA, pers. com.

\section{Tableau I}

Distribution des écrevisses allochtones dans le Latium. $\mathrm{PC}=$ Procambarus clarkii, $\mathrm{OL}=$ Orconectes limosus, $\mathrm{AL}=$ Astacus leptodactylus. 1,2 Dr P.T. COLOMBARI, com. pers. ; ${ }^{3}$ SCALICI \& GIBERTINI, 2002 ; 4 DÖRR et al., $2001 ;{ }^{10}$ Dr M. IACONELLI, com. pers. ; ${ }^{11}$ GIUCCA, $1997 ;{ }^{13}$ Garde-moniteur, com. pers. ; ${ }^{15}$ Prof. P. MARIOTTINI, com. pers. ; ${ }^{16}$ Garde-moniteur, com. pers. ; ${ }^{17} \mathrm{Dr}$ M. LORENZETTI, com. pers. ; ${ }^{18} \mathrm{Dr}$ G. MOTISI, com. pers. ; ${ }^{19} \mathrm{Dr}$ D. CELAURO, com. pers. ; ${ }^{20}$ Dr G. LARICCIA, com. pers.

\begin{tabular}{|c|l|l|l|c|c|c|}
\hline & Province & \multicolumn{1}{|c|}{ Locality } & \multicolumn{1}{|c|}{ Site } & PC & OL & AL \\
\hline \hline 1 & Viterbo & Marta & Marta River & + & & \\
\hline 2 & Viterbo & Gradoli, Bolsena, Capodimonte & Bolsena Lake & + & & \\
\hline 3 & Viterbo & Castel Sant'Elia & Fosso del Ponte & + & \\
\hline 4 & Rieti & Madonna della Luce & Piediluco Lake & + & \\
\hline 5 & Rieti & Rivodutri & Fosso Rivodutri & + & \\
\hline 6 & Rieti & Rivodutri & Riserva Nat.Parz. Laghi Lungo e Ripasottile & + & & + \\
\hline 7 & Rieti & Borgo S.Pietro & + & \\
\hline 8 & Roma & Nazzano & Salto Lake & & + \\
\hline 9 & Roma & Casale Marcigliana & Tevere River & + & \\
\hline 10 & Roma & Dike of Castel Giubileo - Roma & Private area & Tevere River & + & \\
\hline 11 & Roma & Roma & Low Course of Aniene River & + & \\
\hline 12 & Roma & Roma & Fosso di Vaccina & + & & \\
\hline 13 & Roma & Torre Flavia & Torre Flavia Natural Monument & + & \\
\hline 14 & Roma & Ponte Galeria - Roma & Tevere River & + & & \\
\hline 15 & Roma & Pomezia & Cava Tacconi & + & \\
\hline 16 & Roma & lenne & Private area & & + \\
\hline 17 & Latina & Foce Verde & Private area & + & \\
\hline 18 & Latina & Borgo S.Michele & Private area & + & \\
\hline 19 & Latina & Fogliano & Circeo National Park & + & \\
\hline 20 & Latina & Caprolace & Circeo National Park & & \\
\hline 21 & Latina & S.Isidoro & Canale Bonifica Pontina & + & \\
\hline
\end{tabular}




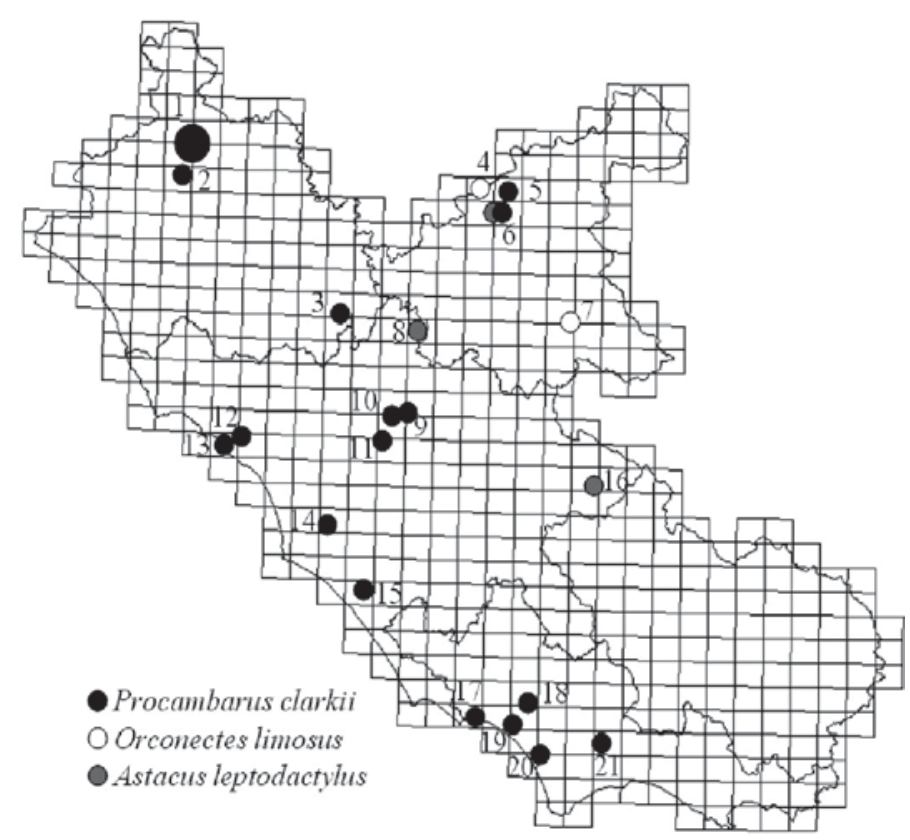

Figure 2

Occurrence of allochthonous freshwater crayfishes in Latium.

\section{Figure 2}

Signalements d'écrevisses allochtones dans le Latium.

As for Astacus leptodactylus, only the geographical distribution has been investigated, due to the limited number of animals collected during the samplings and to the difficult tracing operations, since the species is present in private areas. Consequently, the following analyses have been carried out exclusively for the cambarids.

\section{Measurements}

In total, 153 specimens of Procambarus clarkii (92 males and 61 females) coming from the Circeo National Park (province of Latina) caught in July 2003, and 63 individuals of Orconectes limosus (33 males and 30 females) coming from the Salto Lake (province of Rieti), caught in July 2004, have been measured, taking CTL, TL and W.

The mean values of CTL are $33.6 \mathrm{~mm}( \pm 11.6)$ for $P$. clarkii females and $36.2 \mathrm{~mm}$ $( \pm 11.1)$ for P. clarkii males; $28.1 \mathrm{~mm}( \pm 9.7)$ for 0 . limosus females and $23.9 \mathrm{~mm}( \pm 8.7)$ for $O$. limosus males. The mean values of $W$ are $10.1 \mathrm{~g}( \pm 9.7)$ for $P$. clarkii females and $14.4 \mathrm{~g}( \pm 13.8)$ for P. clarkii males; $7.2 \mathrm{~g}( \pm 7.6)$ for $O$. limosus females $11.4 \mathrm{~g}( \pm 10.8)$ for $O$. limosus males. The sex ratio, calculated as $n^{\circ}$ males $/ \mathrm{n}^{\circ}$ females, is $1.5: 1$ for $P$. clarkii, and 1.1: 1 for 0 . limosus.

The regression analysis between CTL vs. TL and CTL vs. W for females and for males of both cambarids has been carried out using a low number of specimens, because some of them presented malformations of the rostrum and/or chelae. The results are shown in Table II.

For every function the $\mathrm{R}^{2}$ correlation value and the statistical significance are respectively shown. 


\section{Table II}

Regression functions CTL vs. TL and CTL vs. W in P. clarkii and O. limosus.

Tableau II

Fonctions de régression CTL vs. TL et CTL vs. W de $P$. clarkii et $O$. limosus.

\begin{tabular}{|c|c|c|c|c|c|}
\hline \multirow{5}{*}{$\begin{array}{l}\frac{\bar{y}}{\frac{1}{d}} \\
\frac{0}{0} \\
0\end{array}$} & Sex & Function & $\mathrm{N}^{\circ}$ ind & $\mathbf{R}^{2}$ & p \\
\hline & $\mathrm{F}$ & $T L=1.89 \cdot C T L+2.2$ & 55 & 0.98 & $<0.05$ \\
\hline & $M$ & $T L=1.84 \cdot C T L+3.213$ & 76 & 0.98 & $<0.05$ \\
\hline & $\mathrm{F}$ & $W=0.18 \cdot e^{0.10 C T L}$ & 55 & 0.94 & $<0.05$ \\
\hline & $M$ & $W=0.21 \cdot e^{0.10 C T L}$ & 76 & 0.95 & $<0.05$ \\
\hline \multirow{5}{*}{ 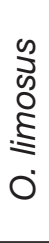 } & Sex & Function & $\mathrm{N}^{\circ}$ ind & $\mathbf{R}^{2}$ & $\mathbf{P}$ \\
\hline & $\mathrm{F}$ & $\mathrm{TL}=2.02 \cdot \mathrm{CTL}+1.61$ & 30 & 0.99 & $<0.05$ \\
\hline & $\mathrm{M}$ & $\mathrm{TL}=2.31 \cdot \mathrm{CTL}+11.12$ & 33 & 0.92 & $<0.05$ \\
\hline & $\mathrm{F}$ & $W=0.08 \cdot e^{0.14 C T L}$ & 30 & 0.82 & $<0.05$ \\
\hline & $M$ & $W=0.39 \cdot e^{0.12 C T L}$ & 33 & 0.90 & $<0.05$ \\
\hline
\end{tabular}

The $\mathrm{K}_{\mathrm{c}}$ values have been calculated by analysing the length-weight regression. They are $1 \cdot 10^{-2}$ and $0.4 \cdot 10^{-2}$ respectively for $P$. clarkii females and males. As for O. limosus, they are $9 \cdot 10^{-3}$ for females and $7.4 \cdot 10^{-1}$ for males. The values of $b$ are 3.16 for $P$. clarkii females and 3.4 for $P$. clarkii males, and 3.28 for $O$. limosus females and 2.2 for $O$. limosus males.

\section{Length-frequency analysis}

The length-frequency diagrams were obtained using $1 \mathrm{~mm}$ size class (Figure 3), using the same samples described in the last paragraph ("measurements").

The analysis of the diagrams showed a division of the sample into 3 age classes (from $0+$ to $2+$ ) for P. clarkii, and into 4 age classes (from $0+$ to $3+$ ) for $O$. limosus. The modal progression analysis on data set has not been processed by sex separately according to ANASTACIO and MARQUES (1995); FIDALGO et al., (2001).

Table III shows the number of specimens for each class, their respective average length, the standard deviation, and the S.I. value. The distribution into age classes obtained with the Bhattacharya method is statistically significant for both P. clarkii $\left(\chi^{2}=19.6, g l=15, p<0.05\right)$ and 0 . limosus $\left(\chi^{2}=16, g l=5, p<0.05\right)$.

The parameters of the Von Bertalanffy growth curve, calculated by applying the mean values of the single age classes, are: $L_{\text {inf }}=62.1 \mathrm{~mm} ; \mathrm{k}=0.79, \mathrm{t}_{0}=-0.1$ for $P$. clarkii, and $\mathrm{L}_{\text {inf }}=54.7 \mathrm{~mm} ; \mathrm{k}=0.71 ; \mathrm{t}_{0}=-0.2$ for $\mathrm{O}$. limosus. Figure 4 shows the curves that have been obtained.

\section{Diet analysis}

To carry out evaluations on the feeding habits of $P$. clarkii and O. limosus, 151 (90 from males and 61 from females) and 61 (33 from males and 28 from females) coming from the two main sites (Circeo National Park in 2003 and Salto Lake 2004) stomachs have been respectively analysed. As for the quantitative analysis, in total 28 empty stomachs has been found in P. clarkii, corresponding to $18.54 \%$; and 12 in O. limosus, corresponding to $19.67 \%$.

As for the qualitative analysis, in the full stomachs of the red swamp crayfish the contents observed have been divided into 4 categories: animal components (crayfishes 

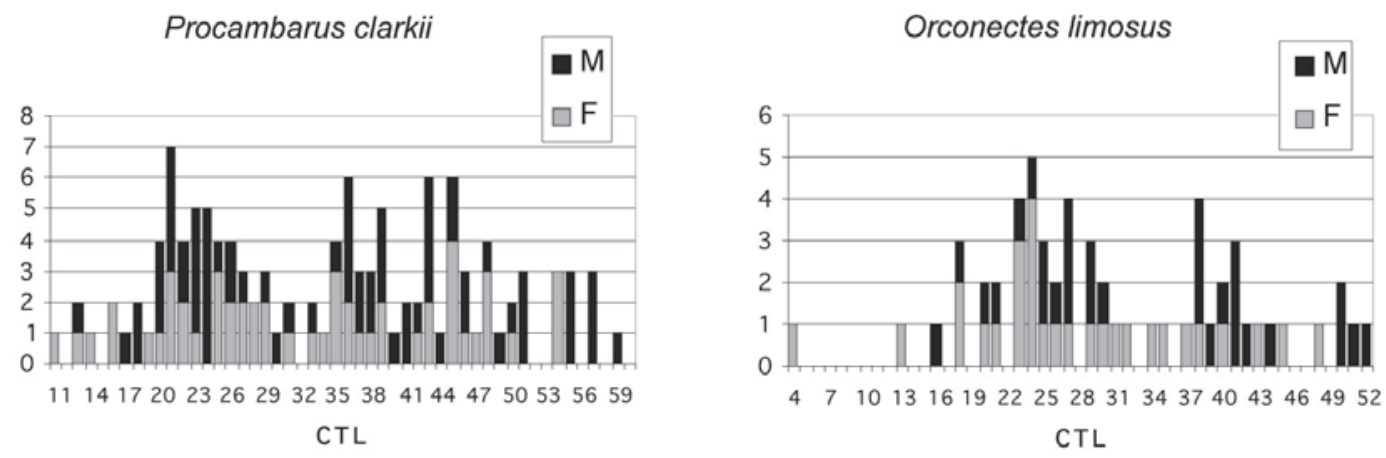

Figure 3

Length-frequency diagrams of $P$. clarkii and $O$. limosus ( $M=$ males, $F=$ females).

\section{Figure 3}

Diagrammes de longueur-fréquence de $P$. clarkii et $O$. limosus ( $\mathrm{M}=$ mâles, $F=$ femelles).

Procambarus clarkii

$\mathrm{CTL}=62.1 \times(1-\exp (-0.79 \times(\mathrm{T}-(-0.1))))$

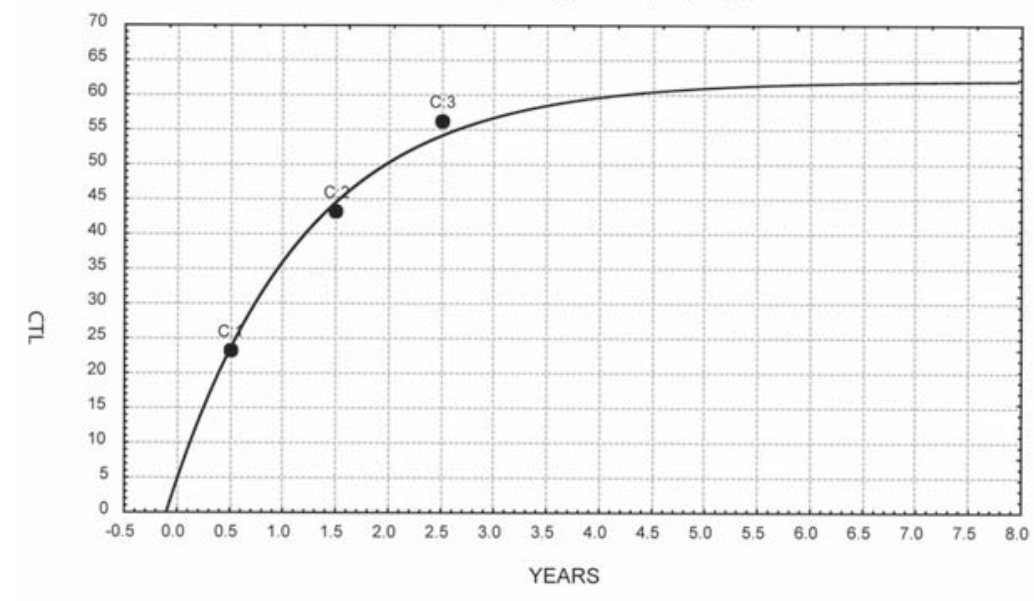

Orconectes limosus

$\mathrm{CTL}=54.7 \times(1-\exp (-0.71 \times(\mathrm{T}-(-0.2))))$

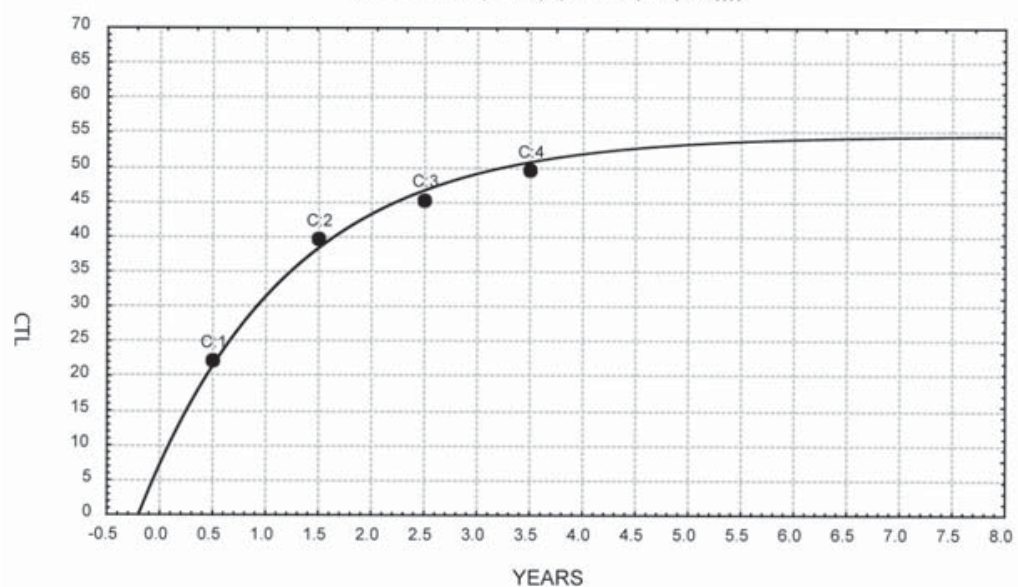

Figure 4

Growth curves of $P$. clarkii and $O$. limosus.

Figure 4

Courbes de croissance de $P$. clarkii et $O$. limosus. 
Table III

Age classes of $P$ clarkii and $\boldsymbol{O}$. limosus $(\mathbf{N}=$ number of individuals, $\mathrm{M}=$ mean length, DS = standard deviation, S.I. = separation index).

Tableau III

Classes d'âge de $P$. clarkii et $O$. limosus $(\mathrm{N}=$ nombre d'individus, $\mathrm{M}=$ longueur moyenne, DS = écart type, S.I. = index de séparation).

\begin{tabular}{|c|c|c|c|c|c|}
\hline & & $\mathbf{N}$ & $M$ & DS & S.I. \\
\hline \multirow{3}{*}{$\begin{array}{l}\frac{\sqrt{\frac{\pi}{0}}}{0} \\
0\end{array}$} & $0+$ & 45 & 23.21 & 3.36 & - \\
\hline & $1+$ & 66.95 & 42.41 & 4.32 & 4.76 \\
\hline & $2+$ & 13.34 & 56.81 & 2.53 & 4.05 \\
\hline \multirow{4}{*}{ 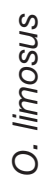 } & $0+$ & 28 & 22.06 & 5.12 & - \\
\hline & $1+$ & 11.77 & 39.57 & 1.73 & 5.11 \\
\hline & $2+$ & 2.23 & 45.30 & 1.68 & 3.37 \\
\hline & $3+$ & 2.98 & 49.50 & 1.21 & 2.92 \\
\hline
\end{tabular}

parts - limbs, stomach, carapace fragments -, ostracods, insects - fragments and larvae of Diptera, elytra of Coleoptera, heads of Hymenoptera, Hemiptera -, mollusc eggs, and fish remains - otoliths, scales, branchial bones); vegetal components (algae, fragments of stalks and seeds of Ceratophyllum, buds and vegetal fibers); detritic component (mucilage, sand and fine particulate sediment); nylon fragments and threads have been classified as other. The same analysis for the American crayfish has pointed out 4 categories as well: animal components (crayfishes parts - limbs, carapace fragments - complete insects or their fragments - Diptera, Hemiptera -, and not identified bone fragments); vegetal components (algae, fragments of seeds, stalks and buds); detritic component (mucilage, sand and fine particulate sediment); nylon fragments and threads, plastic and polystyrene have been classified as other. Finally, occurrence frequencies of the 4 food items (animal,

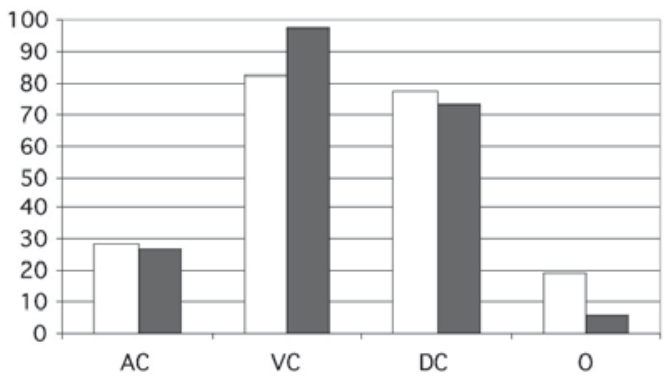

O.limosus

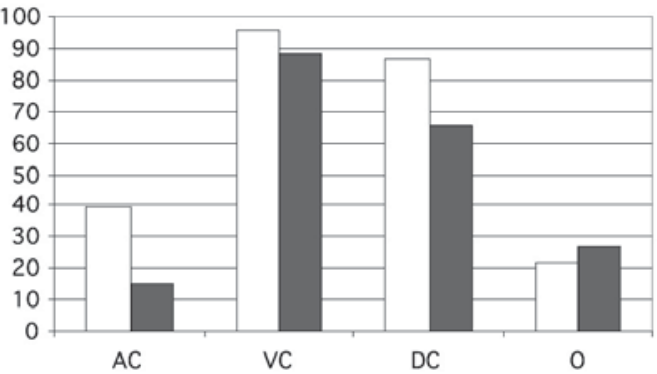

Figure 5

Frequency of occurrence of the stomach content (Y-axis expressed as $\%$ ) in $P$. clarkii and O. limosus: females in white and males in grey (AC = Animal component, $\mathrm{VC}=$ Vegetal component, $\mathrm{DC}=$ Detritic component, $\mathrm{O}=$ Other).

\section{Figure 5}

Fréquences dans l'estomac (exprimé en \% sur les ordonnées) de P. clarkii et O. limosus: femelles en blanc et mâles en gris ( $A C=$ composant animal, $\mathrm{VC}=$ composant végétal, $\mathrm{DC}=$ composant détritique, $\mathrm{O}=$ autre). 
vegetal, detritic, and other) have been calculated for both species (Figure 5). For both $P$. clarkii and O. limosus, the differences found in the occurrence frequencies between males and females are not statistically significant, except for the animal component of the latter $\left(\chi^{2}=9.58, \mathrm{gl}=1, \mathrm{p}<0.01\right)$.

\section{Histology and gonadic index}

The analysis of the histological slides has allowed to identify the different maturity phases of the gonads in the cambarids and to determine the period and the minimum size at which the mature gametes are present. In the female $P$. clarkii the mature oocytes have been observed to be more frequent in July ( $57 \%$ of specimens caught), in individuals with a minimum size of $27.75 \mathrm{~mm}$ CTL. Gonads proved to be empty in the $14 \%$ of individuals caught in July and in the $50 \%$ of that of October. Moreover, an ovigerous female was caught in October 2003. As for the males, mature spermatozoa have been observed in all individuals, the highest values of which has been observed in March $(60 \%$ of specimens). In this month also mature spermatophores (characterized by a layered wall) have occurred, they were present in the $20 \%$ of the individuals, even if they have been observed with higher frequency in the samples of July (60\% of individuals) and October ( $50 \%$ of individuals). Furthermore, from March until July, and especially in March $(20 \%$ of specimens caught), empty gonads have been studied. The minimum size at which mature spermatozoa have been observed was $20.7 \mathrm{~mm}$ CTL.

The mean values of the gonadic index in P. clarkii are $0.32( \pm 0.3)$ for females and $0.15( \pm 0.2)$ for males.

In O. limosus, among the females caught mature gonads have not been observed. This has prevented the identification of the minimum maturity size. On the contrary, as for the males, mature spermatozoa have been found in the specimens caught in June $(50 \%$ of the sample) and August (60\%), with mature spermatophores in individuals that were caught in July (100\% of specimens) and August (40\%). Moreover, in June a juvenile with $4.5 \mathrm{~mm}$ CTL was caught. The minimum size at which mature spermatozoa are present is $24.85 \mathrm{~mm}$ CTL.

The mean values of the gonadic index in O. limosus are $0.31( \pm 0.2)$ for females and $0.36( \pm 0.3)$ for males.

In both species and sexes, the values of the gonadic index have not shown a linear relationship with CTL (Figure 6).

\section{DISCUSSION}

The distribution of the allochthonous freshwater crayfishes in Latium highlighted some differences between them: Orconectes limosus and Astacus leptodactylus are present in restricted areas, while Procambarus clarkii has a wide distribution throughout the region. These differences may be traced back to the great number of records obtained, in relation to the occurrence of the red swamp crayfish, which is by now well known even among people who are not experts in this field. The great interest for this species from a commercial and fishing point of view, could represent the basis of the rapid dispersion that has been observed in the past years, which, together with the great vagility of the species (GHERARDI and BARBARESI, 2000), has contributed to the creation of the present situation. As for $O$. limosus, the fishing interest towards this species seems to be limited to the Salto lake populations. It may be possible that its introduction, as for Astacus leptodactylus, was accidental, during restocking activities of Austropotamobius italicus in the 80s (MANCINI, 1986).

The last observations carried out on cambarids show and confirm their plasticity (especially in $P$. clarkii), the way in which they are able to exploit the numerous resources of environments in which they have been introduced. 

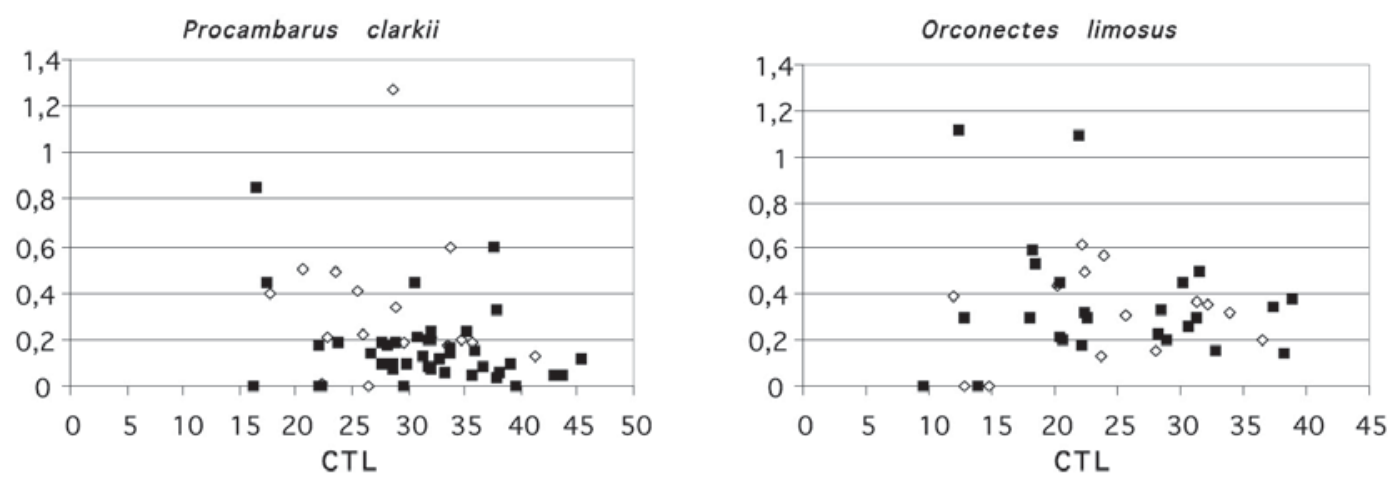

Figure 6

Relationship between G.I. and CTL in P. clarkii and O. limosus (females in white and males in black).

\section{Figure 6}

Rapport entre I.G. et CTL de P. clarkii et $O$. limosus (femelles en blanc et mâles en noir).

Indeed, P. clarkii is able to adapt itself to new environments and shows a high tolerance to the most variable environmental conditions (HOBBS et al., 1989), which, associated to a high growth rate (HUNER, 1978) and a successful reproductive strategy, allows for the development of highly dense populations.

This can be reinforced by the results that have been obtained on the $b$ constant, which is always higher than 3 and represents an allometric growth (which is due to a higher weight increase, more than to the length). These values may be compared to those obtained by other authors in Spain (GUTIÉRRIEZ-YURRITA et al., 1994; GUTIÉRRIEZYURRITA et al., 1996; GUTIÉRREZ-YURRITA and MONTES, 1999) and Portugal (CORREIA, 1993). The constant $K_{c}$ as well shows similar values between the two sexes, as previously observed by other authors (CORREIA, 1993; GUTIÉRRIEZ-YURRITA et al., 1994; GUTIÉRRIEZ YURRITA et al., 1996). The sex ratio shows higher values for males, unlike shown in other studies (i.e. ANASTÁCIO and MARQUES, 1995; FIDALGO et al., 2001), but it complies with what has been observed by OLUOCH (1990) in Kenya, COSTA et al. (1996) in the Azores, GUTIÉRRIEZ-YURRITA et al. (1996) and PÉREZ-BOTE et al. (2000) in Spain, FRUTIGER et al. (1999) in Switzerland and DELMASTRO (1999) in Italy. Here, GHERARDI et al. (1999b) have observed a balanced sex ratio, except for June (when males prevail) and October (when females prevail). Thus, this parameter seems to vary according to the geographic area and the period in which the caught is carried out.

The analysis carried out with FiSAT, has allowed for the identification of 3 age classes for $P$. clarkii, according to what has already been observed by LOZANO-GUERRA and ESCAMILLA-NIÑO (1995). The authors have described three size groups: subadults, adults and adults that survive through a second reproductive season. Moreover, HUNER (2002) sustains that their life has a maximum duration of 4 years, while the mean life in nature does not exceed the 12-18 months, conversely FRUTIGER et al. (1999) have described how the majority of the individuals live through the third year and how the bigger ones can live up to five years of age. As for the values of the von Bertalanffy growth parameters, for $P$. clarkii $\mathrm{L}_{\text {inf }}$ corresponds to what has already been observed by FIDALGO et al. in 2001, $\left(\mathrm{L}_{\text {inf }}=62.01 \mathrm{~mm}\right)$, but the $\mathrm{k}$ and $\mathrm{t}_{0}$ values have been proved different. However, they are very similar to those observed by ANASTÁCIO and MARQUES in 1995 $(k=0,7)$. 
Orconectes limosus as well shows a high invasive ability due to its resistance to pollutants, to the crayfish plague and to high fecundity. This has frequently lead to the substitution of the authochtonous species in many Eastern European Countries (PIEPLOW, 1938; SCHWENG, 1973; STYPINSKA, 1979; ORZECHOWSKI, 1984). The values of the von Bertalanffy growth parameters of $O$. limosus have shown how this species has a slower growth rate compared to the red swamp crayfish. The growth constant $b$ of males is $<3$, while that of the females is $>3$. This matches what has been observed by VAN DEN BRINK et al. (1988), for non-ovigerous females $(b=3,58)$. However, it shows different results for the males ( $b=3,82$ see VAN DEN BRINK et al., 1988). In our case, the results show that in the latter the length increases more with regard to the weight, while as for females the weight increases more than the length, this is probably due to the bigger energy need, which is necessary for the development of the eggs. This corresponds to what we have observed even for $k_{c}$. However, it differs from the results of the authors who have been precedently quoted and who have not highlighted significant differences in the growth between males and females. As for the sex ratio the results show an almost equal relationship between the sexes, confirming what has been observed by BOTT (1950) and by VAN DEN BRINK et al. (1988), who have observed seasonal variations of the sex ratio, with almost equal values for males and females during the summer. Our results have underlined the existence of 4 age classes, while SHULTZ and SMIETANA (2001) have described up to 6 age classes for the females. HAMR (2002) claims that the mean life has duration of 2 years, and the maximum duration is 4 years (ANDREWS, 1907; KOSSAKOWSKI and ORZECHOWSKI, 1975; SMITH 1981; VAN DEN BRINK et al., 1988, MOMOT, 1988).

As for the diet, both species have shown a great ability to utilize the various trophic resources, confirming the fact that they are omnivorous species. However, without distinction between the sexes, it emerges that the vegetal component clearly prevails, followed by the detritic and animal components, as already observed for P. clarkii (GUTIÉRRIEZ YURRITA et al., 1998). The occurrence of cannibalism (NYSTRÖM, 2002) has to be confirmed, because the crayfish fragments found may be derived from exuviae and not from living animals. The preference for the vegetal component may result extremely noxious for the water plants (GARCÍA-MURILLO et al., 1993; GUTIÉRREZYURRITA and MONTES, 1999; ACQUISTAPACE et al., 2004). In P. clarkii, the absence of feeding differences between males and females, already observed by GUTIÉRRIEZ YURRITA et al. (1998), may be due to the fast growth of the species. Indeed, metabolic differences between the sexes have not been previously observed (GUTIÉRRIEZ YURRITA et al., 1994). Conversely, in O. limosus, the differences in the animal component between males and females may be due to the metabolism of the latter, whose oogenesis would require a higher quantity of energy.

As for the reproduction, these preliminary observations on gonadal maturation, may suggest that the $P$. clarkii breeding occurs in Latium between the summer and the autumn. Besides, the occurrence of an ovigerous female in October confirms what has been reported by other Italian authors, GHERARDI et al. (1999b) for the province of Florence, and DELMASTRO (1999) for Piedmont, where ovigerous females have been found during the summer. Most probably, the species is able to breed twice a year, even during the spring, as already observed by some authors (CANO and OCETE, 1997; GUTIÉRREZYURRITA and MONTES, 1999), outside its original distributional area. However, to confirm this hypothesis further researches are necessary, to clearly identify the breeding period, with a special attention to the occurrence of ovigerous females, and females with larvae. As suggested by the same GUTIÉRREZ-YURRITA and MONTES (1999), this species is very likely able to breed during the whole year: the entire process may vary in relation to the environmental conditions, allowing the species to easily adapt itself to the most varied ecosystems and naturalise even in geographic areas that are different to its primary distributional area. HUNER (1981) suggests that in favourable conditions there may be up to three generations each year. Studying reproduction has highlighted how the sexual 
maturity may be reached in females at $27.75 \mathrm{~mm} \mathrm{CTL}$, corresponding to $54.7 \mathrm{~mm} \mathrm{TL}$, and in males at $20.7 \mathrm{~mm}$, equal to $41.3 \mathrm{~mm}$ TL. HUNER (2002) describes this value as very variable, ranged from $45 \mathrm{~mm}$ to $125 \mathrm{~mm}$ TL or more. Moreover, the duration of the reproductive period, the rapid growth, the early sexual maturity and the short mean life, may even explain the result observed confronting CTL with the gonadic index, which was difficult to interpret, and supplied by the histological method. As for O. limosus, the occurrence in July and August of sexually mature males matches the data reported by HAMR (2002) for Quebec (primary distributional area), where the breeding takes place in spring (March-April) and again in September-October. Besides, the occurrence in June of a newly independent juvenile confirms what reported by the same author even in Europe, where the breeding takes place in spring and eggs are carried by the female until JuneJuly, period in which they hatch. Also VAN DEN BRINK et al. (1988) in the Netherlands have observed the occurrence of ovigerous females from March until June, with the highest value in April, and in May females with juveniles attached to the abdomen. This may suggest the existence of a wide reproductive interval that allows the species to breed more times during the year. However, even in this case, further researches are necessary to clearly identify the breeding period in the population examined. In males observed by us, the sexual maturity is reached at $24.85 \mathrm{~mm}$ CTL. HAMR (2002) quotes a unitary value of 25-35 mm CTL for European populations, and $45 \mathrm{~mm}$ CTL for those of Quebec. Even in this case, the frequency of the breeding periods may explain the result of the gonadic index with respect to CTL, which is difficult to interpret.

\section{CONCLUSION}

Identifying managerial activities that may eradicate or at least reduce the great problems caused by the allochthonous crayfish, represents a difficult operation, due to the current situation in Latium, region which shows, especially in the province of Latina and partially in that of Rome, a morphology of the territory and of the rain-collecting basins water system extremely heterogeneous and complex. In these conditions the eradication of the allochthonous species, especially the red swamp crayfish, would require a considerable economic and field effort.

It is necessary to aid the manual removal of exotic crayfishes with other more efficient methods. Even though the feasibility of eradication and monitoring activities of populations of non-native crayfishes has been discussed in several studies (i.e. HOLDICH et al., 1999; HOWARD, 2000; KEMP, 2000; SIBLEY and NÖEL, 2002), insecticides, herbicides, or fungicides seem to potentially represent one of the most efficient instruments (LAURENT, 1995). However, these may bring forth a great number of negative effects on other animal and plant species.

While bringing along an eradication programme it is, nonetheless, necessary to consider the economic importance that these species have acquired in the past years. To bring into force a managerial activity that concerns the monitoring or the eradication, it is necessary that the methods used 1) are safe for the environment, 2) represent a high probability of success, 3) are inexpensive, 4) do not harm human health, 5) are explicable to the public (HOLDICH et al., 1999). Due to the difficulties in identifying methods that comprehend all these characteristics, the best compromise, which is acceptable from an ecologic, economic and ethic point of view, must be achieved according to a process defined as "situationality" (GHERARDI and ANGIOLINI, 2002). In this case, as for the eradication of $O$. limosus only from the Salto lake, the eradication is difficult to carry out, since it may influence the economy of a small but consistent social reality, which uses this species as an important resource and which is long called by locals "ours" (authochtonous). In this context, the planning of environmental managerial interventions, compatible with the socio-economic and cultural needs of the local populations, is fundamental, in order 
to get their approval and involve them in their achievement, increasing the probability of success. Moreover, the impossibility of approaching, in some cases, populations of allochthonous crayfishes, as for the Turkish crayfish, should make one reflect. In this case private property has represented a great obstacle.

Nonetheless, it is necessary to act as soon as possible to avoid the worsening of the current conditions, using simultaneously, if possible, different strategies. Control is the conservation activity that seems to have the greatest possibility of success. In this context, the use of pheromones is a method proposed by other authors (HOLDICH et al., 1999; KEMP, 2000; SIBLEY and NÖEL, 2002) as a potential means of control of invasive allochthonous species. STEBBING et al. (2004) have studied the use of these substances showing how, with the attraction of reproductive Pacifastacus leniusculus males, it is possible to control the populations of undesired crayfishes. This has to be integrated with a constant and practical monitoring of the territory, which may certainly reduce the possibility of dispersion of these species. In this sense even an instrument like the GIS (Geographic Information System) may contribute to the identification of potentially apt areas to the dispersion and the colonization from undesired species (SCALERA, 2001). Furthermore, territorial control means prevention of transfaunation. Internationally speaking, as for this sector, more than 140 countries, among which Italy, have adhered to a regulation of the Convention on International Trade in Endangered Species of Wild Flora and Fauna (CITES). However, inside national boundaries there are no specific laws that regulate fish transport, especially of decapods, and not even specific organisms dealing with this problem (MAIO, 2002). This allows free transport in every area of the region and of the national territory, with clearly obvious consequences.

Thus, it is important to highlight the need to regulate legal instruments suitable to control the fishing activities and prohibit a further introduction of the species in other sites. Even the establishment of areas similar to the no-go English areas (HOLDICH and REEVE, 1991), anyhow criticised by some experts of the field, may represent a useful solution, provided that it is reinforced by valuable laws and tangible controls.

Moreover, it is important to be aware of the scarce interest from citizens to these problems and simultaneously start a programme of environmental education on more levels (that means for a wide public starting from students up to adults and those who have limited knowledge of this field). This may greatly help to create awareness, not only in the public opinion, but also in every person dealing with sportfishing and professional fishing.

\section{ACKNOWLEDGEMENTS}

The authors would like to thank Dr. M. Lombardi and Dr. V. Cortellini, who kindly translated the manuscript in English, and Julien Dubois who helped with the translation into French. We also thank Dr. P. Avetrani for his invaluable help during the fieldwork.

\section{REFERENCES}

ACQUISTAPACE P., CACCHIANI A., GHERARDI F., 2004. Impatto esercitato dal gambero invasivo, Procambarus clarkii, sulla comunità acquatica di un ambiente di particolare interesse faunistico e floristico. $10^{\circ}$ Congresso Nazionale A.I.I.A.D. "La gestione dell'ittiofauna per la tutela e la conservazione degli ambienti fluviali". Montesilvano (Pe), 2-3 Aprile, 21.

ALDERMAN D.J., POLGLASE J.L., 1988. Pathogens, parasites and commensals. In: HOLDICH D.M. and LOWERY R.S. (eds.), Freshwater Crayfish: Biology, Management and Exploitation. Croom Helm, London, 167-212. 
ANASTÁCIO P.M., MARQUES J.C., 1995. Population biology and production of the red swamp crayfish Procambarus clarkii (Girard) in the lower Mondego river valley, Portugal. J. Crustacean Biol., 15 (1), 156-168.

ANDREWS E.A., 1907. The young of the crayfish Astacus and Cambarus. Smithsonian Contributions to Knowledge, 35, 5-79.

ARDIZZONE G.D., BELLUSCIO A., GRAVINA M.F., SOMASCHINI A., 1996. Colonization and disappearance of Mytilus galloprovincialis Lam. on an artificial habitat in the Mediterranean Sea. Estuarine, Coastal, and Shelf Science, 43, 665-676.

BARBARESI S., GHERARDI F., 2000. The invasion of the alien crayfish Procambarus clarkii in Europe, with particular reference to Italy. Biological Invasions, 2, 259-264.

BHATTACHARYA C.G., 1967. A simple method of resolution of a distribution into Gaussian components. Biometrics, 23, 115-135.

BOTT R., 1950. Die Flusskrebse Europas (Decapoda, Astacidae). Abhandl. Senchenberg. Naturf. Ges., 483, 1-36.

Van Den BRINK F.W.B., Van Der VELDE G., GEELEN J.F.M., 1988. Life history parameters and temperature related activity of an American crayfish, Orconectes limosus (Rafinesque, 1817) (Crustacea, Decapoda), in the area of the major rivers in the Netherlands. Archives für Hydrobiologia, 114, 275-289.

CADDY J.F., 1987. Size-frequency analysis for crustacea: moult increment and frequency model for stock assessment. Kuwait Bull. Mar. Sci., 9, 43-61.

CANO E., OCETE M.E., 1997. Population biology of the red swamp crayfish Procambarus clarkii (Girard, 1852) in the Guadalquivir river marshes, Spain. Crustaceana, 70 (5), 553-561.

CONFORTINI I., NATALI M., 1994. Presenza del gambero americano Orconectes limosus (Rafinesque, 1817) in alcuni corsi d'acqua della Pianura Veronese (Crustacea Decapoda Cambaridae). Ann. Mus. Civ. Rovereto, 10, 399-404.

CORREIA A.M., 1993. Length-weight relationships for two populations of red swamp crayfish, Procambarus clarkii (Decapoda, Cambaridae) from Portugal. Freshwater Crayfish, 9, 442-450.

CORREIA A.M., FERREIRA O., 1995. Burrowing behaviour of the introduced red swamp crayfish Procambarus clarkii (Decapoda: Cambaridae) in Portugal. Journal of Crustacean Biology, 15 (2), 248-257.

COSTA A.C., CORREIA A.M., RODRIGUES M.L., 1996. Monitoring a population of Procambarus clarkii in São Miguel (Azores, Portugal). Freshwater crayfish, 11, 203212.

DELMASTRO G.B., 1992a. Sull'acclimatazione del gambero della Louisiana Procambarus clarkii (Girard, 1852) nelle acque dolci italiane. Pianura 4, 5-10.

DELMASTRO G.B., 1992b. II gambero americano Orconectes limosus (Rafinesque), un nuovo decapode neartico nelle acque dolci del Nord Italia (Crustacea Decapoda Cambaridae). Natura Bresciana. Ann. Mus. Civ. Sc. Nat., Brescia, 27, 171-174.

DELMASTRO G.B., 1999. Annotazioni sulla storia naturale del gambero della Louisiana Procambarus clarkii (Girard, 1852) in Piemonte Centrale e prima segnalazione Regionale del gambero americano Orconectes limosus (Rafinesque, 1817) (Crustacea: Decapoda: Astacidae: Cambaridae). Riv. Piem. St. Nat., 20, 65-92.

DÖRR A.J.M., PEDICILLO G., LORENZONI M., 2001. Prima segnalazione in Umbria di Procambarus clarkii (Girard), Orconectes limosus (Rafinesque) e Astacus 
leptodactylus Eschscholtz, (Crustacea Decapoda). Riv. Idrobiol., 40 (2-3), 221233.

FIDALGO M.R., CARVALHO A.P., SANTOS P., 2001. Population dynamics of the red swamp crayfish, Procambarus clarkii (Girard, 1852) from the Averio Region, Portugal (Decapoda, Cambaridae). Crustaceana, 74 (4), 369-375.

FRUTIGER A., BORNER S., BÜSSER T., EGGEN R., MÜLLER R., MÜLLER S., WASMER H.R., 1999. How to control unwanted populations of Procambarus clarkii in Central Europe? Proceedings of the 12th Symposium, International Association of Astacology, Augsburg, Bavaria, Germany 1998. Freshwater Crayfish, 12, 714726.

GALLUPPI R., MAZZONI D., QUAGLIO F., TAMPIERI M.P., 1996. Episodio di mortalità in gamberi turchi (Astacus leptodactylus) di importazione. Atti del Convegno Nazionale "Il contributo dei progetti di ricerca allo sviluppo dell'acquacoltura nazionale", 4753.

GARCIA S., LE RESTE L., 1981. Life cycles, dynamics, exploitation and management of coastal penaeid shrimps stocks. FAO Fish. Tech. Pap., 203, 205 pp. (Issued also in French and Spanish).

GARCÍA-MURILLO P., BERNUÉS M., MONTES C., 1993. Los macrofítos acuáticos del Parque Nacional de Doñana: aspectos florísticos. Actas del VI Congreso Español de Limnología, 31-43.

GAYANILO Jr. F.C., SPARRE P., PAULY D., 1996. The FAO ICLARM stock assessment tools (FiSAT) user's guide. FAO Computerized Information Series (Fisheries), Rome, FAO, 8, 1-126.

GENOVESI P., 2002. Introduzioni biologiche: impatto sulla biodiversità e priorità di azione per il futuro. Atti del Convegno Nazionale "La gestione delle specie alloctone in Italia. II caso della nutria e del gambero rosso della Louisiana", Firenze, 2425 Ottobre, 75-80.

GHERARDI F., ANGIOLINI C., 2002. Eradication and control of invasive species. Encyclopedia of Life Support Systems, EOLSS-UNESCO, Eolss Publishers, Oxford, UK., vol. III, chp 16.6,

GHERARDI F., BALDACCINI G.N., BARBARESI S., ERCOLINI P., DE LUISE G., MAZZONI D., MORI M., 1999a. Alien crayfish in Europe: the situation in Italy. In: GHERARDI F. and HOLDICH D.M. (eds.), Crayfish in Europe as alien species. How to make the best of a bad situation? 107-128.

GHERARDI F., BARBARESI S., 2000. Invasive crayfish: activity patterns of Procambarus clarkii in the rice fields of the Lower Guadalquivir (Spain). Archiv für Hydrobiologie, 150 (1), 153-168.

GHERARDI F., RADDI A., BARBARESI S., SALVI G., 1999b. Life history of the red swamp crayfish (Procambarus clarkii) in an irrigation ditch in Tuscany, Italy. The biodiversity crisis and crustacea: Proceedings of the Fourth International Crustacean Congress, Amsterdam, The Netherlands, July 20-24, 1998, 99-108.

GIBERTINI G., QUATTROCCHI L., BONIFAZI A., MELONI M., 1998. Gamberi autoctoni ed alloctoni nella Riserva dei Laghi Lungo e Ripasottile e nella Provincia di Rieti. Consorzio Riserva Naturale Laghi Lungo e Ripasottile, 22 p.

GIUCCA F., 1997. Nuove segnalazioni relative all'ittiofauna del tratto urbano del fiume Tevere (Roma). Atti del I ${ }^{\circ}$ Convegno Nazionale Sulla Fauna Urbana, Roma, 12 Aprile, 127-129. 
GROPPALI R., 1993. Sulla presenza del gambero americano Orconectes limosus (Rafinesque) in acque della Pianura Pavese (Crustacea Decapoda Cambaridae). Riv. Piem. St. Nat., 14, 93-96.

GUTIÉRREZ-YURRITA P.J., BRAVO-UTRERA M.Á., JORDÁ J.R., BALTANÁS A., MONTES C., 1994. Análisis preliminar de la tasa metabólica estandar en el cangrejo rojo, Procambarus clarkii (DECAPODA: CAMBARIDAE), en el bajo Gualquivir (S. España). Limnética, 10 (1), 123-128.

GUTIÉRREZ-YURRITA P.J., ILHÉU M., MONTES C., BERNARDO J., 1996. Morphometrics of red swamp crayfish from a temporary Marsh (Doñana National Park, Sw. Spain) and a temporary stream (Pardiela stream, S. Portugal). Freshwater Crayfish, 11, 384-393.

GUTIÉRREZ-YURRITA P.J., MONTES C., 1999. Bioenergetics and phenology of reproduction of the introduced red swamp crayfish, Procambarus clarkii, in Doñana National Park, Spain, and implications for species management. Freshwater Biology, 42, 561-574.

GUTIÉRREZ-YURRITA P.J., SANCHO G., BRAVO M. Á., BALTANÁS A., MONTES C., 1998. Diet of the red swamp crayfish Procambaus clarkii in natural ecosystems of the Doñana National Park temporary freshwater marsh (Spain). Journal of Crustacean Biology, 18 (1), 120-127.

HAMR P., 2002. Orconectes. In: Biology of freshwater crayfish. HOLDICH D.M. (ed.). Blackwell Science, Oxford, 585-608.

HOBBS H.H. III., JASS P., HUNER J.V., 1989. A review of global crayfish introductions with particular emphasis on two North American species (Decapoda, Cambaridae). Crustaceana 56 (3), 229-316.

HOLDICH D.M., 2003. Crayfish in Europe. An overview of Taxonomy, Legislation, Distribution, and Crayfish Plague Outbreaks. Proceedings of a conference held on 7th November 2002 at the Nottingham Forest Football Club, Notthingham, UK, 15-34.

HOLDICH D.M., GYDEMO R., ROGERS W.D., 1999. A review of possible methods for controlling nuisance populations of alien crayfish. In: GHERARDI F., HOLDICH D.M. (eds.), Crayfish in Europe as alien species. How to make the best of a bad situation? Rotterdam: A.A. Balkema, 245-270.

HOLDICH D.M., REEVE I.D., 1991. Distribution of freshwater crayfish in the British Isles, with particular reference to crayfish plague, alien introduction and water quality. Aquatic Conservation: Marine and Freshwater Ecosystem, 1, 139-158.

HOGGER J.B., 1984. A report on some of the first introductions of Pacifastacus leniusculus into the UK. Freshwater Crayfish, 6, 134-145.

HOWARD G.W., 2000. Control options: freshwater invasives. Paper presented to the workshop on Best Management Practices for preventing and controlling Invasive Alien Species. Cape Town, South Africa.

HUNER J.V., 1978. Crayfish population dynamics as they afffect production in several small, open commercial crayfish ponds in Louisiana. Proceedings of the Annual Meeting Of The World Mariculture Society, 9, 619-640.

HUNER J.V., 1981. Information about the biology and culture of the red swamp crayfish, Procambarus clarkii (Girard, 1852) (Decapoda, Cambaridae) for fisheries managers in Latin America. Anales del Instituto de Ciencias de Mar y Limnologia de la Universidad National Autónoma de México, 8, 43-50. 
HUNER J.V., 2002. Procambarus. In: Biology of freshwater crayfish. HOLDICH D.M. (ed.). Blackwell Science, Oxford. 541-584.

HUNER J.V., BARR J.E., 1991. Red swamp crayfish: Biology and Exploitation, $3^{\text {rd }}$ edn. Louisiana Sea Grant College Program, Louisiana State University, Baton Rouge, Louisiana.

JAMIESON G.S., BOURNE N., 1986. North Pacific Workshop on stock assessment and management of invertebrates. Can. Spec. Publ. Aquat. Sci., 92, 430 p.

KEMP E., 2000. Eradication of alien crayfish populations. R\&D Technical Report W1-037, Final Report. The Environment Agency and English Nature Bristol: Environment Agency, Bristol.

KOSSAKOWSKI J., ORZECHOWSKI B., 1975. The crayfish Orconectes limosus in Poland. Freshwater Crayfish, 2, 31-47.

LAURENT P.J., 1995. Eradication of unwanted crayfish species for astacological management purposes. Freshwater Crayfish, 8, 121-133.

LEONARDI E., ARDIZZONE G.A., 1994. Biology of Aristaeomorpha foliacea along the Latium Coast (Central Tyrrhenian Sea). Proceedings of the International Workshop "Life cycles and fisheries of the deep-water red shrimps Aristaeomorpha foliacea and Aristeus antennatus". Istituto di tecnologia della pesca e del pescato. BIANCHINI M.L., RAGONESE S. (eds). N.T.R.-I.T.P.P. Special Publication, 3, 33-34.

LOZANO-GUERRA J., ESCAMILLA-NIÑO A., 1995. Ecology of red swamp crayfish (Procambarus clarkii, Girard) in the Central Meseta of Spain. Freshwater Crayfish, 8, 179-200.

MAIO G., 2002. Specie ittiche alloctone d'acqua dolce: evoluzione storica e stato attuale in Italia. Atti del Convegno Nazionale "La gestione delle specie alloctone in Italia. II caso della nutria e del gambero rosso della Louisiana." Firenze, 24-25 Ottobre, 81-88.

MANCINI A., 1986. Astacicoltura. Allevamento e pesca dei Gamberi d'acqua dolce. Edagricole, Bologna. $180 \mathrm{p}$.

MAZZONI D., NOBILE L., QUAGLIO F., RESTANI R., 1997. Diffusione dei gamberi d'acqua dolce in Emilia Romagna: problemi ecopatologici legati all'introduzione delle specie alloctone. Boll. Soc. It. Patol. Ittica, 21, 45-51.

MERELLA P., ALEMANY F., CARBONELL A., QUETGLAS A., 1998. Fishery and biology of Norway lobster Nephrops norvegicus (Decapoda: Nephrophidae) in Mallorca (western Mediterranean). Journal of Natural History, 32, 1631-1640.

MOMOT W.T., 1988. Orconectes in North America and elsewhere. In: Freshwater crayfish: Biology, Management and Explotation, D.M. HOLDICH and R.S. LOWERY (eds.). Croom Helm, London, 262-282.

NYSTRÖM P., 2002. Ecology. In: Biology of freshwater crayfish. HOLDICH D.M. (ed.). Blackwell Science, Oxford. 192-235.

OLUOCH A.O., 1990. Breeding biology of the Louisiana red swamp crayfish Procambarus clarkii Girard in Lake Naivasha, Kenya. Hydrobiologia, 208, 85-92.

ORSI RELINI L., RELINI G., 1985. An attempt to assign Bertalanffy growth parameters to Aristeus antennatus Risso 1816 (Crustacea Decapoda) of the Ligurian Sea. Rapp. Comm. Int. Mer Médit., 29 (5), 301-304.

ORZECHOWSKI B., 1984. Productivity of the freshwater crayfish Orconectes limosus RAF. (= Cambarus affinis SAY) in Koronowo basin. Acta Univ. Nicolai Copernici Prace Limonol. (Poland) 14, 3-36. 
PÉREZ-BOTE J.L., PULA H.J., CASCOS G., 2000. Distribucíon del cangrejo rojo Procambarus clarkii Girard, 1859 (Decapoda, Cambaridae) en Extremadura. Graellsia, 56, 71-78.

PIEPLOW U., 1938. Fishereiwissenschaftliche Monographie von Cambarus affinis SAY. Zeitschr. Fischerei, 36 (16), 349-440.

QUATTROCCHI L., GIBERTINI G., MANCINI A., BONIFAZI A., 1996. Orconectes limosus (Crustacea: Decapoda: Cambaridae), un gambero esotico d'acqua dolce, nelle acque del Centro Italia. Atti del $57^{\circ}$ Congresso Nazionale Unione Zoologica Italiana. S. Benedetto del Tronto, 24-26 Settembre, 36.

RANTAMÄKI J., CERENIUS L., SÖDERHÄLL K., 1992. Prevention of transmission of the crayfish plague fungus (Aphanomyces astaci) to the freshwater crayfish Astacus astacus by treatment with $\mathrm{MgCl}_{2}$. Aquaculture, 104, 11-18.

SALVI G., 1999. Dieta, preferenze alimentari e potenziale impatto del gambero alloctono Procambarus clarkii sugli ecosistemi invasi. Master Thesis, Università di Firenze.

SALVIDIO S., DELAUGERRE M., 2003. Population dynamics of the European leaf-toed gecko (Eleuptes europaea) in NW Italy: implications for conservation. Herpetological Journal, 13, 81-88.

SCALERA R., 2001. Invasioni biologiche. Le introduzioni di vertebrati in Italia: un problema tra conservazione e globalizzazione. Ministero delle Politiche Agricole e Forestali. Corpo Forestale dello Stato, $368 \mathrm{p}$.

SCALICI M., GIBERTINI G., 2002. I gamberi alloctoni nel Lazio (Italia). Atti del Convegno Nazionale "La gestione delle specie alloctone in Italia. II caso della nutria e del gambero rosso della Louisiana." Firenze, 24-25 Ottobre, 109-115.

SCHULTZ R., SMIETANA P., 2001. Occurrence of native and introduced crayfish in Northeastern Germany and Northwestern Poland. Bull. Fr. Pêche Piscic., 361, 629641.

SCHWENG E., 1973. Orconectes limosus in Deuschtland, insbesondere im Rheingebiet. Fresh. Crayfish, 3, 79-87.

SIBLEY P.J., NÖEL P., 2002. Control and management of alien crayfish. Bull. Fr. Pêche Piscic., 367, 881-886.

SMITH D.G., 1981. Life history parameters of the crayfish Orconectes limosus (Raf.) in southern New England. Ohio Journal of Science, 81, 169-172.

SPARRE P., VENEMA S.C., 1996. Introduction à l'évaluation des stocks de poissons tropicaux. Document technique sur les pêches, 306/1, Rev. 1, Rome, FAO, 401 p.

SPEDICATO M.T., CANNAS A., 2000. La pesca responsabile. In: CATAUDELLA S. and CARRADA G.C. (eds.), Un mare di risorse, introduzione alla conservazione ed alla gestione delle risorse ittiche, 67-135.

STEBBING P.D., WATSON G.J., BENTLEY M.G., FRASER D., JENNINGS R., RUSHTON S.P., SIBLEY P.J., 2004. Evaluation of the capacity of pheromones for control of invasive non-native crayfish. English Nature Research Reports, 578, 39 p.

STYPINSKA M., 1979. Comparison of the species fecundity of crayfishes inhabiting waters of the Mazurian Lakeland. Zool. Pol., 27, 279-289.

ZEKHNINI A., CHAISEMARTIN C., 1991. Structure démographique et éthologie alimentaire de l'écrevisse pallipède (Austropotamobius pallipes) dans quatre cours d'eau. Vie et Milieu, 41 (1), 45-53. 